\title{
A LITERATURE OVERVIEW OF THE SELECTED MARKETING STRATEGIES IN CONTEMPORARY BUSINESS
}

\author{
Katarzyna Łukasik, Małgorzata Iżyńska \\ Czestochowa University of Technology \\ Faculty of Management
}

\begin{abstract}
Streszczenie: This paper considers some of the aspects of using and establishing marketing strategies. The use of a marketing strategy requires the company to be flexible and able to adapt to customer needs. Small businesses usually make small moves in this area even if they have knowledge which allows them to compete in a given area. Regardless of the company size, it is necessary to plan a marketing strategy to allow for efficient and effective management. The main aim of this paper is to present theoretical assumptions of modern marketing strategies using selected social-media capabilities. The article presents an overview of literature from the studied area.
\end{abstract}

Słowa kluczowe: marketing, marketing mix, marketing strategies, strategy, social-media

DOI: $10.17512 /$ znpcz.2018.1.15

\section{Introduction}

Almost all organizations and all institutions regardless of their size create their developmental strategies. It is obvious that a strategy created appropriately determines their future existence. An enterprise that wants to appear or continue operating on the market should take appropriate actions to enable efficient and effective management. Developing a marketing strategy is vital for any business (Tabor 2011, p. 127-143). The purpose of a company`s marketing strategy should be to identify and then communicate the benefits of business offering to the target market. It is obvious that one of the key elements of a successful marketing strategy is the acknowledgment that your existing and potential customers will fall into particular groups or segments, characterized by their needs and expectations. Identifying these groups and their needs through market research and then addressing them more successfully than your competitors should be the focus a corporate strategy (http://www.infoentrepreneurs.org/...).

The main aim of this paper is to present the theoretical assumptions of marketing strategies in contemporary business and the principles of using social media for marketing activities.

\section{Defining strategy and marketing strategy}

The term "strategy" is derived indirectly from Classic and Byzantine Greek (330 A.D.) "strategos", which means "general". The Greek equivalent for the modern word "strategy" would be "strategike episteme" or (general's knowledge) 
"strategon sophia" (general's wisdom) (Horwath 2006). In the thirties of the previous century, it began to refer to such areas of human activity as politics and economics. The theory of management conceived strategies in various ways. Moreover, the diversity of this concept is visible in the national as well as the world literature.

According to Michael Porter's theory from 1996, which was published in an article in Harvard Business Review (Porter 1982; Porter 1996), competitive strategy is "about being different". He also adds that "[i]t means deliberately choosing a different set of activities to deliver a unique mix of value". In short, Porter argues that competitive strategy is about a competitive position, about differentiating the company in the eyes of the customer, about adding value through a mix of activities different from those used by competitors.

Another author, Kenneth Andrews, presents his definition of strategy in his book The Concept of Corporate Strategy (Andrews 1980): "Corporate strategy is the pattern of decisions in a company that determines and reveals its objectives, purposes, or goals, produces the principal policies and plans for achieving those goals, and defines the range of business the company is to pursue, the kind of economic and human organization it is or intends to be, and the nature of the economic and non-economic contribution it intends to make to its shareholders, employees, customers, and communities".

Despite certain differences in the interpretation of the term strategy, we can distinguish several main features (Lukasik, Brendzel-Skowera 2015, p. 494-501; Gierszewska, Romanowska 1998, p. 27):

- continuity,

- complexity,

- coherence,

- flexibility,

- practicability.

A strategy is defined as the plan of an organization associated with its position in the environment (current and future) and a relatively stable and coherent mode of action. It can be assumed that the strategy adopted by a management board of a company creates a coherent operating model, whose implementation is intended to provide fundamental long-term aims under the specific domain of actions.

The essence of an effective strategy is that it creates company uniqueness and enables both the employees and the environment to clearly distinguish a given entity from all other organizations on the market.

A company's strategy is composed of four vital elements: domain of action, strategic superiority, strategic aims and functional programs of action. A corporate strategy provides a general framework for business activities developed by the whole company. It is most frequently used when a company competes only on one market or several strictly associated markets. A global strategy is of paramount importance from the company's perspective because it represents a comprehensive plan for the development. One can observe three crucial types of big strategy: growth strategy, stabilization strategy, and cuts strategy. 


\section{Models of strategies on the market}

Taking into account the role that individual companies play on the market, one can divide companies into the following groups by the type of strategies they use (Ranchhod, Gurau 2007, p. 39-43):

Leaders - market leaders have the largest market share of the product. Generally, a market leader is in the lead in comparison to other companies in the area of pricing, introducing new products, distribution range and the intensity of promotion. Such a company is a point of reference for its competitors. An enterprise in a dominant position on the market tries to keep it as long as possible. The leader must decide which areas of activity will be defended, as it cannot defend all of its positions. One must concentrate its resources on the most relevant areas. In such a situation, the company may apply a defensive strategy the aim of which is to reduce the likelihood of attack, transfer the attack to the less important areas and reduce its intensity.

Pretenders - market contenders are companies in the second and further places in the industry. The primary objective of such companies is to increase their market share, and consequently their profits. To achieve this goal, the challenger can attack the market leader (a very risky but potentially highly profitable strategy), companies with a similar business scale or small local and regional companies. Having a clearly defined goal and an opponent, the pretender must choose an optimal strategy of attack. The starting point is the massive impact principle (basic strength should be maintained for the critical moment and to achieve the most relevant goal).

Followers - companies located in a further position on the market; they prefer to imitate leaders rather than attack. Each imitator tries to afford certain benefits; better distribution system, attractive credit terms, etc. Followers are a common target of contenders. They have to keep low production costs and high product quality as well as enter newly opened markets.

Philip Kotler distinguishes three types of imitating (Kotler 2009, p. 112): "Clone imitating products, distribution and promotion of a leader; Imitator copying some elements of leadership offer; Improver adopting product of a leader".

Market specialists - an alternative to being a follower on a large market is the role of a leader on a small market. Smaller companies avoid competing with large companies by dealing with small segments. This strategy is generally profitable because the specialist recognizes their customers so well that it is capable of satisfying their needs better than other companies. Consequently, the specialist can charge higher prices in exchange for the high value of the product. The main risk of specialization is that the niche may become unpopular and become an easy target of attack. Therefore, a company must take into account that its niche may be weakened and it has to constantly create new market gaps. It may keep its strategy, but not necessarily in this particular niche. Dealing with multiple niches is, therefore, more preferred than having a single specialization. It stems from the fact that the company developing in two or more fields increases its chances of survival. 


\section{The meaning of marketing strategy}

Business Dictionary defines marketing strategy as an organization's strategy that combines all of its marketing goals into one comprehensive plan. A good marketing strategy should be drawn from market research and focus on the right product mix to achieve the maximum profit potential and sustain the business. A marketing strategy is the foundation of a marketing plan (http://www.businessdictionary.com/...).

One of the primary assumptions of the marketing concept is orientating business activities on a specific recipient. The starting point for a definition of a marketing strategy is market orientation, which places consumers and their needs in the spotlight. The reactions of purchasers to the same product and the same market stimulus vary. It demonstrates that on the market there is no average consumer, who could be a useful reference in formulating company directions. Therefore, it becomes particularly important to define and study the differences between consumers and consumer groupings. As a result, it facilitates the capacity to understand the existing and potential buyers (Garbarski, Rutkowski, Wrzosek 2001, p. 168-169).

Consumer grouping in a particular manner constitutes the essence of the process of market segmentation (Sun 2009, p. 63-70).

"Market segmentation is the division of the market, according to a specific criterion into homogenous groups of consumers which determines the area of operations for the company and provides a point of reference for the formulation of a program of action (Rutkowski, Wrzosek 1985, p. 80)". Identification of individual market segments occurs as a result of various criteria, relevant to the market situation (Table 1).

Table 1. Segmentation criteria

\begin{tabular}{|l|l|l|l|l|l|}
\hline \multicolumn{5}{|c|}{ CRITERIA OF MARKET SEGMENTATION } \\
\hline \multicolumn{1}{|c|}{ CONSUMER-RELATED CRITERIA } & \multicolumn{2}{|c|}{ PRODUCT-RELATED CRITERIA } \\
\hline $\begin{array}{l}\text { Socio- } \\
\text { Economic }\end{array}$ & Demographic & Psychographic & $\begin{array}{l}\text { Consumption } \\
\text { patterns }\end{array}$ & $\begin{array}{l}\text { Condition of } \\
\text { purchase }\end{array}$ & Offered benefits \\
\hline $\begin{array}{l}\text { income, } \\
\text { occupation, } \\
\text { education, } \\
\text { geographical } \\
\text { criteria, } \\
\text { place of } \\
\text { residence }\end{array}$ & $\begin{array}{l}\text { age, } \\
\text { gender, } \\
\text { family size, } \\
\text { family life cycle } \\
\text { phase, family } \\
\text { status, } \\
\text { nationality }\end{array}$ & $\begin{array}{l}\text { lifestyle, } \\
\text { activities, } \\
\text { interests, } \\
\text { opinions }\end{array}$ & $\begin{array}{l}\text { frequency of } \\
\text { use, } \\
\text { possession of } \\
\text { other products, } \\
\text { brand loyalty }\end{array}$ & $\begin{array}{l}\text { type of store, } \\
\text { time of purchase, } \\
\text { the nature of the } \\
\text { purchase, the size } \\
\text { of a single } \\
\text { purchase, } \\
\text { frequency of } \\
\text { purchase }\end{array}$ & $\begin{array}{l}\text { consumer } \\
\text { knowledge about } \\
\text { perception of } \\
\text { benefits of buying, } \\
\text { consumer } \\
\text { predisposition }\end{array}$ \\
\hline
\end{tabular}

Source: (Garbarski, Rutkowski, Wrzosek 2001, p. 173)

Market segmentation can be accomplished taking as its starting point a consumer or a product. If the starting point is the consumer, market segments are isolated by grouping consumers with common characteristics. However, if the product is the starting point, the segmentation is performed by grouping consumers 
in accordance with their reaction to the product. A properly identified segment should be characterized by the following four features: measurability, breadth, availability, and sensitivity. The next step in the development of a segmentation strategy is the selection of the target market. This decision forejudges the nature of the company (Doole, Lowe 2008, p. 38-42).

Recognizing and describing market segments available for the enterprise creates an opportunity to take various actions, define a broad area of operations and focus on a particular area of the market.

From the perspective of a company, one can distinguish three management strategies (Ranchhod, Gurau 2007, p. 67):

1. Undifferentiated actions. The company treats the market as a whole and it develops its marketing strategy in relation to this market. This approach may be used when the demand for products and consumer behavior are quite similar. The adoption of this concept means that the company does not use market segmentation.

2. Differentiated actions. The company operates on the market as a whole but does not treat it homogeneously. For the purpose of separate segments, the company prepares separate agendas of the marketing mix.

3. Focused actions. It is the variant of the concept of differentiated activities. The company focuses its actions on the selected segment of the market, adapting the product, pricing, distribution and activation of sales to the characteristics of this segment.

To sum up, a marketing strategy is an answer to the following question: how will the company deliver superior customer values to its market? It requires the formulation of a consistent marketing mix, which includes the following elements:

1. product,

2. price,

4. communications,

5. distribution,

6. services.

\section{Marketing-mix assumptions and goals}

The company which in its management process takes into account marketing has to constantly communicate with the market and act on it. Marketing effectiveness depends primarily on the choice of instruments a company uses to operate on the market. This well-known instrument is called by Borden the "marketing mix" (Lemańska-Majdzik 2015, p. 339-345).

The marketing mix is a set of marketing tools that a company uses to implement the intended marketing objectives on the target market (Pabian 2008, p. 37-44). There exist dozens of tools of the marketing mix. McCarthy popularized the classification of these instruments referred to as the 4Ps: product, price, place-distribution, promotion (Figure 1). 


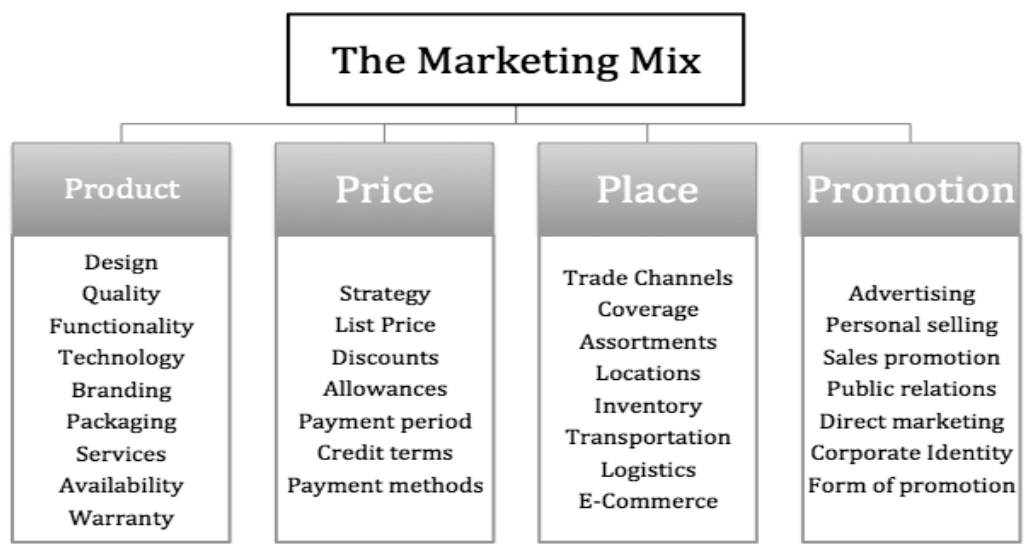

Figure 1. 4Ps Marketing Mix

Source: Own preparation based on (Kotler 2009, p. 90)

The primary tool of the marketing mix is the product, which constitutes the current market offer of an enterprise, including quality, design, technical specifications, brand and packaging. Another important tool is the price, which is the sum of money that customers must pay for the goods. The company must determine wholesale and retail prices, discounts, allowances and conditions of the loan. The price should be proportional to the perceived value of the offer. Otherwise, the purchaser will select the products of competitors. Distribution is another key tool in the marketing mix. It includes the types of operations that a company undertakes to make the product easily available to customers. Promotion, the fourth tool, includes various types of operations undertaken by a company in order to inform about the characteristics of the product and to convince important target purchasers to buy it.

\section{Integration with various media platforms}

Modern technology offers a number of opportunities for today's companies. The customer receives easy access to information about a company and its products, which helps to build customer loyalty and keep them in the organization. There can be distinguished many marketing tools that are very helpful in supporting the marketing activity of a company.

In business today, first impressions are more frequently made by looking at a company's' website than in person. Company`s website must be highly organized, have a clean look, and be easy to navigate. One of the mistakes made by many websites is filling the home page with flash multimedia, such as audio or video. The longer you make the users wait for the page to load, the more likely you are to lose them.

The various media platforms that flow into the center company website are vital to a successfully integrated program. All other media should work in combination, 
delivering one unified message to drive visitors to a website. Popular social media sites include Facebook, Twitter, YouTube, LinkedIn, Instagram and Google+ and are defined by consumers themselves through their opinions, reviews, ratings, and blogs. To be successful, a company must update its social media content frequently. LinkedIn allows you to create a professional profile and connect with other users. It should be treated as an online resume in which a company can display information about itself and its capabilities and contribute to industry discussions. Facebook is similar in the sense of creating a profile, but it takes a more social approach. A company can post photos, videos, and updates on its current projects or certifications. Twitter allows its users to sign up to read items or link to company's posts (http://www.thefabricator.com/article/...).

"As a product of the Mark Zuckerberg generation, it is easy to understand why people are so obsessed with social media; for marketers, the potential to grow their business via these networks is endless. Facebook, Twitter, Pinterest, Instagram these are some of the prime networks on which every company, big or small, young or established, needs be actively present. It is now inexcusable for any business that wants to thrive to not be tweeting" (Figure 2) (http://www.wordstream.com/...). There is no doubt that Facebook enjoys the greatest popularity among all social-media; that is why also companies use it for marketing purposes. Moreover, the other popular social media used for marketing are Instagram, Twitter, the little known in Poland Pinterest, and more and more popular LinkedIn.
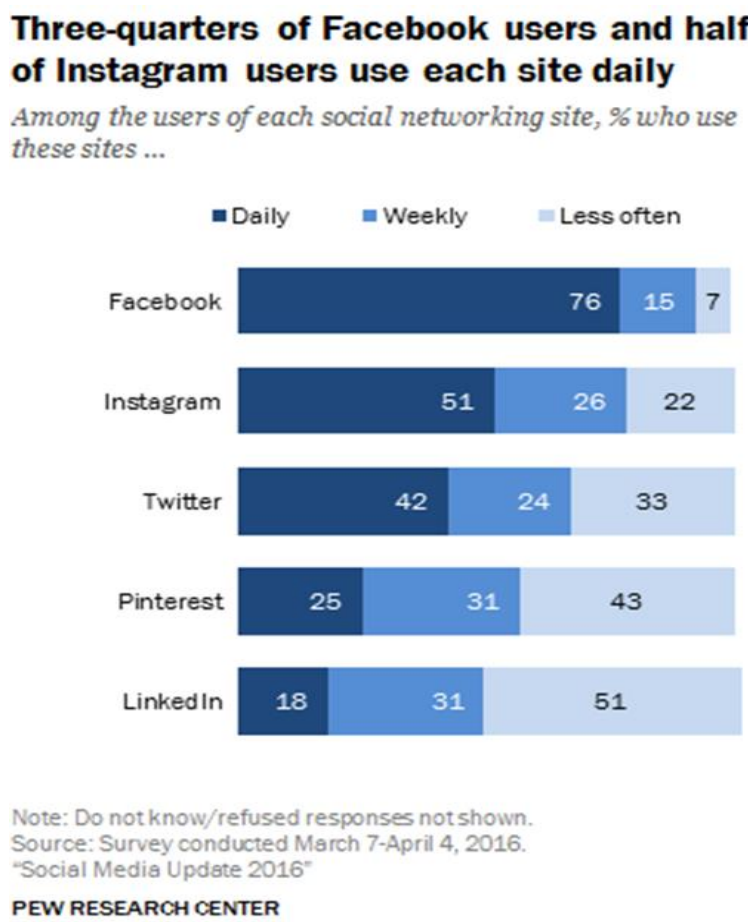

Figure 2. The popularity of social media and their use

Source: (http://www.wordstream.com/...) 
Other social media tools/platforms which are often used for commercial purposes are (https://www.komarketing.com/...):

1) Google Base - any company with a product catalog, can create a data file containing their products and upload it to Google Base free of charge. Products that are submitted to Google Base are populated to Google's Product Search. Some users go directly to Google Product Search to find items, but the majority of traffic generated on this portion of Google's platform comes from the integration of Google Base feeds into the traditional Google.com search results page.

2) YouTube - video content is a great way to provide complex information to customers, prospects, and users. And, while video content has benefits that stand alone, there are also very valuable search engine benefits. Videos can encourage people to link to your website lifting the site's overall link popularity and helping with keyword rankings across the site. Videos are now being increasingly integrated into traditional search engine results. Google's ownership of YouTube and its increasing efforts to integrate varying content types into search results has now made this more common.

Content and social media have a symbiotic relationship: without great content social media is meaningless and without social media nobody would know company's products. They have to be used together to reach and convert a company's prospects. There are three main components of any successful social media content strategy: type of content, time of posting and frequency of posting. The type of content that should be posted on each social network relies on form and context. Form is how that information will be presented - text only, images, links, video, etc. (https://www.socialmediaexaminer.com/...).

\section{Conclusions}

An effective marketing strategy combines product development, promotion, distribution, and pricing. The marketing mix and customer relationship management and can serve as a basis for a company's marketing plan. However, over 50\% of Polish companies have a formulated marketing strategy. Almost 35\% of companies operate in the form of a written record, and $22 \%$ of companies have "heads" of executives, according to the "Marketing Strategies 2014" report prepared by the Mind Progress Group in collaboration with the IPC Research Institute. In the age of ubiquitous opportunities for business development, it seems that the biggest difficulty in planning a good marketing plan is the company's financial constraints and time-consuming process. However, it is necessary to function efficiently on a modern and quite demanding market. A marketing strategy is an ever-evolving work, and it is important for its creators to know what the company's ultimate goal is. Such a strategy can only exist in the manager's head, and only the strength of their personality causes them to know what to do at the appropriate moment. 


\section{Literature}

1. Andrews K. (1980), The Concept of Corporate Strategy, 2nd Edition, Dow-Jones Irwin.

2. Doole I., Lowe R. (2008), International Marketing Strategy: Analysis, Development and Implementation, South-Western Cengage Learning, USA.

3. Garbarski L., Rutkowski I., Wrzosek W. (2001), Marketing - punkt zwrotny nowoczesnej firmy, PWE, Warszawa.

4. Gierszewska G., Romanowska M. (1998), Myślenie strategiczne, "Przegląd Organizacji”, nr 6, p. 27.

5. Horwath R. (2006), The Origin of Strategy, http://www.strategyskills.com/Articles_Samples/ origin_strategy.pdf (accessed: 10.04.2017).

6. http://www.businessdictionary.com/definition/marketing-strategy.html (accessed: 06.04.2017).

7. http://www.infoentrepreneurs.org/en/guides/create-your-marketing-strategy/ (accessed: 08.04.2017).

8. http://www.thefabricator.com/article/shopmanagement/strategic-marketing-formanufacturers (accessed: 10.04.2017).

9. http://www.wordstream.com/blog/ws/2014/01/09/social-media-marketing-strategies (accessed: 10.04.2017)

10. https://komarketing.com/blog/7-search-marketing-strategies-for-manufacturers-distributors/ (accessed: 09.04.2017)

11. https://www.socialmediaexaminer.com/essential-elements-social-media-marketing-strategy/ accessed: 07.05.2017).

12. Kotler P. (2009), Marketing Management, Pearson Education, Edinburgh.

13. Lemańska-Majdzik A. (2015), Selected Elements of Marketing Mix in the Operation Services Companies on the Real Estate Market - Results of Own Studies, [in:] International Conference Hradec Economic Days 2015. Economic Development and Management of Regions. Hradec Kralove, 3-4 February 2015, Peer-Reviewed Conference Proceedings, Vol. 4, Gaudeamus, Hradec Kralove, p. 339-345.

14. Lukasik K., Brendzel-Skowera K. (2015), The Marketing Strategies of Polish Company on the EU Market - an Example, [in:] International Relations 2015. Current Issues of World Economy and Politics. 16th International Scientific Conference, Smolenice, Slovakia, Publishing House Ekonom, Bratislava, p. 494-501.

15. Pabian A. (2008), Marketing mix i jego instrumentarium, [in:] Pabian A. (red.), Środki i formy marketingowego oddziaływania na konsumentów, Wydawnictwo Politechniki Częstochowskiej, Częstochowa, p. 37-44.

16. Porter M.E. (1982), Cases in Competitive Strategy, Free Press, New York.

17. Porter M.E. (1996), What is Strategy?, "Harvard Business Review" (Nov-Dec), p. 61-78.

18. Ranchhod A., Gurau C. (2007), Marketing Strategies: A Contemporary Approach, Financial Times / Prentice Hall, 2nd Edition, England.

19. Rutkowski I., Wrzosek W. (1985), Strategie marketingowe, PWE, Warszawa

20. Sun S. (2009), An Analysis on the Conditions and Methods of Market Segmentation, "International Journal of Business and Management", Vol. 4, No. 2, p. 63-70. DOI: 10.5539/ ijbm.v4n2p63

21. Tabor J. (2011), Marketing of Purchases and Technological Strategies in Small- and Medium-Sized Enterprises, [in:] Howaniec H., Waszkielewicz W. (eds.), Marketing and Logistics Problems in the Management of Organization, Wydawnictwo Naukowe Akademii Techniczno-Humanistycznej w Bielsku-Białej, Bielsko-Biała, p. 127-143. 


\section{PRZEGLĄD LITERATURY NA TEMAT WYBRANYCH STARTEGII MARKETINGOWYCH WE WSPÓŁCZESNYM BIZNESIE}

Streszczenie: W artykule rozważano niektóre z aspektów wykorzystywania i opracowywania strategii marketingowych we współczesnym biznesie. Opracowanie strategii marketingowej wymaga od firmy elastyczności i dostosowania do potrzeb klienta. Małe firmy zazwyczaj sceptycznie podchodzą do korzystania z niestereotypowych narzędzi marketingowych, nawet jeśli ich możliwości są im dobrze znane i mogą dać ogromną przewagę konkurencyjną. Niezależnie od wielkości firmy należy zaplanować strategię marketingową umożliwiającą sprawne i skuteczne zarządzanie. Głównym celem opracowania jest prezentacja teoretycznych założeń nowoczesnych strategii marketingowych przy wykorzystaniu wybranych możliwości social-mediów. W artykule został dokonany przegląd literaturowy w badanego obszaru.

Keywords: marketing, marketing-mix, strategia, strategie marketingowe, social-media 